\title{
2 \\ Developing leadership and building executive capacity in the Australian public services for better governance
}

\section{Peter Allen and John Wanna}

\section{Introduction}

Australian governments have invested in public sector training and development since the pre-Federation decades in the last quarter of the nineteenth century. Dedicated training to impart basic skills and routines in the embryonic public services of colonial times was immediately recognised as a necessity across all the established Australian jurisdictions - first, the colonial states, then the Federal Government and subsequently in the territories and at local government levels - with each conducting their own training programs to suit their own needs and requirements. Historically, various central oversight bodies (such as public service boards and commissions with statutory independence) were charged explicitly with responsibility for ensuring training and development in departments and agencies, with official reports and commissions of inquiry charting progress, highlighting problems and recommending courses of action (Parker 1993; Caiden 1967; Spann 1973). 
In this chapter, we suggest that public sector training in Australia has evolved from informal on-the-job training supported by 'in-service' programs aimed at conveying basic administrative requirements, functional tasks and operating procedures to more formalised, externally provided, qualification-based educational development and training. The latter tended to take one of two directions: professional education involving specialist forms of expertise and technical skilling; or the inculcation of more generically inspired managerial capabilities and familiarisation with emerging organisational and work perspectives - operation and maintenance (O\&M), management by objectives (MBO), financial and human resource skills, computing and technology, as well as fashionable managerial philosophies such as 'new public management' or 'public value' approaches. In recent years, Australian governments have focused on developing strategic leadership skills and building executive capacities in and across public organisations and their network partners or service providers.

This chapter locates public sector training within Australia's traditions of governance. It briefly explores the historical development and increasing importance of educational qualifications and formalised training programs. It then reviews the changing patterns of demand for types of training and skills development, the evolving curricula and professional orientation of training and the changing composition and roles of training providers (the supply side), going from 'in-house' training units to generalist educational institutions and eventually to specialist consultant providers. In the Australian context, executive development programs have increasingly become integrated within formal staff appraisal processes and performance review systems, while at the same time such philosophies have shifted from transmitting basic technical skills to thinking about developing organisational human resource capabilities, and eventually to the encouragement of team-based problem-solving leadership potentialities (AIM 2013). The chapter finishes with a case study of the Australia and New Zealand School of Government (ANZSOG), a unique interjurisdictional and intervarsity executive development institution dedicated to growing executive capabilities not only among its Australasian members but also in the wider Pacific region. ${ }^{1}$

1 The authors would like to thank Professors Gary Banks and Andrew Podger for comments and suggestions on earlier drafts. 


\section{Public services shaped by Australian traditions of governance}

Australia, like New Zealand, inherited its main political traditions in the nineteenth century from its colonial power, the United Kingdom, including ideas about the formation of governments, election systems, political parties and the nature of its public services across the various self-governing colonies. Westminster-derived notions of 'responsible government' (with an elected executive responsible to parliament under a constitutional monarchy with vestiges of crown privilege) were transplanted to Australian shores from the British motherland along with the desire to populate the 'New World' with white settlers comprising deported convicts and free-settler émigrés (see Patapan et al. 2005). British traditions of small ' $c$ ' constitutionality (Magna Carta, habeas corpus, parliamentary sovereignty, the rule of law, consent and tolerance, and so on) underscored the main Westminster political traditions involving a reliance on pragmatic political conventions, majoritarianism, a strong executive held 'responsible' to parliament, competing political parties and loyal opposition. These were foundational principles, with some local adaptations, in the Australian colonies and in the new federal administration after 1901.

These governing traditions also informed notions about the nature of public administration and the institution of the public serviceparticularly the 'fused' but subservient relationship with formal politics (the elected executive) - as well as its normative roles and responsibilities, hierarchical structure and organisation, composition and skill base, recruitment and promotion and internal administrative cultures (see Podger 2003). To outsiders, the British character of public administration has often been categorised as dilettantish or amateurish, fundamentally class-ridden and too reliant on its reputed 'good chap' sensibilities towards serving in public office (Hennessy 1988). Australia and New Zealand followed the United Kingdom in establishing a permanent civil service, which in the Antipodes enjoyed a formal statutory status that codified an observed separation (and protection) from politics (essentially eschewing ministerial involvement in senior appointments). Australian public services were conceived as permanent apparatuses of state, loyal and obedient to the government of the day, but apolitical, neutral and anonymous (Crisp 1972; Spann 1973). Public service organisations (ministerial departments 
and statutory authorities) were administratively interdependent with government, having professionally to work closely with cabinet and its ministers and so become to some extent politically savvy without being politically active. Over time, public servants developed considerable administrative expertise, advisory skills and effective relations with elected (and frequently changing) ministries. If politicians became regarded as the temporal and alternating rulers of government, public officials were often conceived of as permanent institutions of the state imbued with the techniques of statecraftat least until the 1970s and 1980s, when some of their privileges were withdrawn and contestability for advice became more commonplace (Davis and Rhodes 2000).

State-level public services generally date from the mid-1850s, with the federal administrative institutions now approaching 115 years of age-previously called the Commonwealth Public Service but now known as the Australian Public Service (APS). These public services (now nine separate jurisdictions) all became career services, generally unified as a jurisdictional workforce, enshrining the principles of continuity, neutrality, anonymity and largely internal notions of merit (Caiden 1965). They typically recruited from schoolleaver entrants who saw public service as their sole vocation, closed off from the wider labour market, offering internal promotion opportunities and providing lifetime employment (historically this was primarily open only to males, because various prohibitions on married women removed them from the service and allowed career employment only to non-married women, until the bar on married women was lifted from the 1960s). The various services were staffed by a combination of predominantly generalist administrators with some specialist professions. They were highly insular and not open to 'strangers' (very little lateral recruitment or 'lateral entry' from outside), and increasingly became bureaucratically industrial in their employment orientations (with strong public sector unions organised by administrative categories). For decades, governments and their central personnel management agencies (the public service boards) were preoccupied with improving the quality and reliability of administration, including economy and efficiency, routinisation and consistency of administrative practice, due diligence, compliance accountability and ethics (PSMPC 2001). More recently, these perennial bureaucratic issues have tended to be overshadowed (but not totally 
displaced) by the imperatives of improved management, greater reliance on business techniques and conceptual skills, performance and program effectiveness over results and outcomes, capacity building, developing outward-oriented cultures of responsiveness and client-focused forms of service delivery, and consultative practices and public engagement.

\section{Australia's 'training-for-purpose' approach to public service training and executive development}

There are some standard features of Australia's approach to training and development in the public service that have not changed unduly over time. Australian public services remain career services, with the majority of officials enjoying continuing employment (through to the most senior Band 3-level Senior Executive Service (SES) appointments with reversionary employment rights even if they are serving on more lucrative three to five-year contracts). Entering administrative recruits generally start at the bottom (base-grade clerical) and progress through the service via internal promotion routes not usually open to outside competition as they accumulate on-the-job experience and achieve competencies. Training and development for public servants were not a statutory requirement (and are not mentioned in older or newer versions of the various Public Service Acts), but service-wide bodies and individual agencies maintained an enduring interest in 'training for purpose'. Most of the larger agencies tended to operate their own training activities (and could contract external providers for specific workshops), while central agencies (public service boards or commissions) retained some overall service-wide responsibilities, including coordination and ensuring agencies fulfilled their training and executive development obligations. Accordingly, most training and development were fragmented and conducted at the individual agency level, with considerable in-service delivery and customised on-the-job training. Taken together, these training regimes formed a matrix of self-administered, 'job-focused' training, generally characterised by piecemeal provision, internally provided with short-term focuses, stop-start in delivery and 'not for credit' - that is, they did not count as upper secondary or tertiary qualifications. 
These in-service offerings - resourced primarily at the individual agency level - could be supplemented at the individual officer level with formal 'out-service' instruction 'for credit' (qualification-based programs delivered by business and secretarial colleges, night schools and further education colleges, dedicated training institutes and universities).

Significantly, however, no Australian or New Zealand jurisdiction has invested in a single monopoly provider of training services. There has never been an equivalent in Australia or New Zealand of the central civil service colleges, such as the centrally funded Singapore Civil Service College or the Taiwanese National Academy of the Civil Service, with service-wide responsibilities for training and development. This is not to say that there have not been constant tensions between and debates over the merits of agency-specific 'training for purpose' and the 'holy grail' of devising centrally coordinated generic training regimes. ${ }^{2}$

\section{The evolution of public service training and development}

Gerard Caiden once wrote that the traditional approach to public service careers in Australia has stressed the recruitment of young school-leavers who could be trained on the job and promoted according to promise and performance' (1967: 217). But this was not the full picture as, even at the time he was writing, about half the Commonwealth and state public services comprised returned servicemen who were given preferred employment status and who had relatively limited schooling. Returned servicemen, with limited educational levels and policy capabilities, posed a major dilemma for the public service because by the time these officials had reached their 40s and 50s, further training was of questionable value and few were likely to volunteer for (or be accepted in) formal courses in tertiary institutions. Central personnel agency control and direction of training were most pronounced between the 1940s and the 1980s (with some centrally designed and delivered generic courses, although

2 For example, the Public Service Board established the Central Training Section in 1947 to plan and coordinate training activities, especially systematic training of clerical and administrative staff. 
there were debates about whether the board should seek to provide training that was available through external providers; see Caiden 1967). Before and after these decades, line agencies themselves tended to take responsibility for their own training needs or, in the later period, looked to the market.

Service-wide interest in training began in the late 1930s, mainly encouraging job rotation in departments and supporting external studies by individual officers (see Appendix 2.1 for key milestone dates of training provision). By the late 1940s, routine in-service training consisted of induction sessions for new recruits (new entrant schools), procedural training related to compliance and specific administrative tasks (claims handling, benefit assessments, investigation procedures, safety and maintenance work, machine operation, technician training) and refresher courses to ensure better performance and reliability (correspondence and report writing, dictation and typing, improved reading, work simplification, bookkeeping, and so on) (Betts 1949; Caiden 1967: 219). Even from the late 1920s and early 1930s there was some scope for recruiting a handful of graduates for nonprofessional clerical divisions, and some encouragement for public servants to undertake 'outside studies' at night schools or colleges of further education. From the 1950s, public services gradually (and sometimes reluctantly) tried to make themselves more attractive employers, recruiting graduate intakes (still in very limited numbers), cadet entrants and from administrative trainee schemes. ${ }^{3}$ By the 1960s greater emphasis was placed on professional skills and data analysis (administrative data processing), usually as an investment in potential human capital (and university cadetships that 'bonded' the individual recipients for up to five years with the public service). As well, jurisdictions paid particular attention to entry-level training, new entrant induction programs and professional skills development directly linked to merit and promotion (not organisational seniority). Senior administrative staff and professional grades were given their own selective training-from senior management conferences to executive development programs and mentoring/coaching schemes.

3 In 1962 the Public Service Board (PSB) celebrated the recruitment of 93 graduates into the clerical division, commenting that the figure was the 'highest for many years' (Caiden 1965). The 44th PSB Annual Report, for 1968, listed the annual intake of graduate appointments from 1933 to 1967; the intake ranged from none or one or two to 200 or 300 with the main growth only occurring from the mid-1960s. 
However, much in-service training remained experience-related, where the twin objectives were 'to see that an individual knows what to do without being told and to see that he is more receptive when he is told' (Spann 1973: 84). There is little evidence that training needs were closely aligned with 'manpower planning' or with thinking about future workplace human resource needs.

In the 1970s as policy work expanded, the number of graduates entering the various services increased. While most of those in the higher grades (first and second divisions) were graduates by the late 1970s, only 1,748 new graduates were appointed into the clerical division in 1975 - up from 884 in 1969 and only 212 in 1959 . By 1978 quota limits on the number of entering graduates were abolished and, gradually, as they rose through the ranks, these more educated public servants stressed the importance of knowledge and intellectual and analytical abilities. Yet although the numbers of graduates increased significantly (rising to almost 4,000 per annum by the early 1980s), very few had any formal tertiary training in public administration (but more would have had social science training, including government or political science degrees). By the 1980s, the focus had shifted to middle-management training and business and management training, often with graduates undertaking subsequent graduate diplomas and master's courses in professional areas, including Master of Business Administration (MBA), law and accounting masters. Internal training tended then to focus on competency-based training, gap analysis for required skills and selective recruitment. A frequent structure for courses was based on three themes: technical skills, interpersonal skills and self-management skills (PSC 1992: 37-8). A government-mandated training guarantee program in the early 1990s requiring agencies to spend 2 per cent of their budgets on training saw the proliferation of many private-sector training organisations and providers of organised conferences on work-related topics under the banner of training. In addition, a number of senior executive services (SESs) had been created by the early 1990s across the jurisdictions, and specialist development programs were devised for this cohort, including a dedicated induction program called SEMP. Executive development relied on a formal leadership capability framework to broaden capabilities and develop high-performance leadership (by encouraging people to develop executive capabilities to shape strategic thinking, cultivate productive working relations, 
communicate with influence, exemplify personal drive and integrity and achieve results) (see APSC 2004). At the same time, a 'cooperative venture' between all the Australian jurisdictions and a consortium of universities provided middle-management development courses with formal university qualifications (graduate certificate), called the public sector management course (PSMPC 2001: 191). As the 2000s progressed, many jurisdictions adopted forms of an 'integrated leadership framework' applying to their SES and other executive levels (see APSC 2004; Chapter 1, this volume).

\section{Changing dynamics of demand}

Demands for training were historically decentralised in origin, driven by agency needs and often provided by agencies themselves. In the APS, training was historically seen as a means of transmitting departmental cultures, norms and procedures as well as administrative capabilities. Usually the agencies employing the staff chose the course topics and types of training provided and the quantum of attendees. Individual agencies also funded the training they provided themselves or paid for outside providers from within their budgets (and accepted the costs associated with deploying staff away from normal duties). Agencies naturally focused on their own immediate needs and purposes, and the training was not particularly anticipatory or strategic in content. Some agencies developed extensive in-house training programs, some of which were compulsory for new recruits and middle-level officials. But in-house training with its focus on agency-specific vocational on-the-job experience had its limitations, which were gradually apparent across the public services from the 1960s.

Government departments and individual public servants both energised the demand for formal qualifications (tertiary degrees, advanced diplomas, graduate diplomas, masters by coursework) as endemic 'credentialism' manifested itself in the public service. Almost all new recruits possessed graduate qualifications (or were close to graduating), and many were sponsored to undertake (relevant) higher-level studies, especially vocationally oriented masters courses - for example, public policy, policy studies, public management, accounting or generic business studies. Universities 
and technical and further education (TAFE) colleges expanded their vocational offerings as well as beginning to tap the part-time student and distance-education markets. But, at the same time, traditional courses in the building blocks of public administration tended to decline as an academic specialisation, replaced with more generic courses in business techniques, organisational design, human resource management, computing studies and information technology (Davis and Wanna 1997). The number of institutions offering postgraduate MBAs increased from two in the 1970s to more than 30 by the late 2000s, and these business-oriented higher degrees were, for a while, remarkably popular with public servants and their departmental supervisors. Eventually rivalling this development of generic business credentialism was the establishment of a number of dedicated public policy tertiary courses (some offered at the undergraduate level but most provided at the masters level to graduates) (see the survey of Australian university public policy/public management centres/ degrees by Di Francesco 2015). Enrolments across tertiary institutions increased from 200,000 in 1985 to 600,000 by 2014 , forming a huge pool of educated jobseekers from which to recruit staff.

Australia also saw the growth of specialist professional institutions delivering executive education. Along with the Workers' Education Association (dating back to the nineteenth century with mechanics' institutes), there arose dedicated training centres such as the Australian Administrative Staff College (AASC, a residential executive college established in 1954), which later became the Mount Eliza Business School, and then merged in 2004 with the Melbourne Business School of the University of Melbourne. There was also increased provision from various professional bodies such as the various public service commissions, the Australian Institute of Management (AIM) and the Institute of Public Administration of Australia (see AIM 2013). These professional bodies tended to provide professionally oriented and vocational training, stressing 'learning and development' and often concentrated on some generic capabilities - for example, public policy skills, business and management techniques, accounting and specialist law programs and health and safety training. Learning and development were typically based on a 70:20:10 pedagogic model, with 70 per cent related to on-the-job training, 20 per cent learnt through networks and relations and 10 per cent through formal education programs. A host of private sector training and executive 
development providers also sprang up from the 1980s, often headed by former top executives from the public and private sectors-for example, the Centre for Public Management (CPM), YellowEdge and Timmins \& Stewart Consulting.

Within government, attention to high-level specialised executive development became a focus from the 1950s, and various programs succeeded one another to target and prepare future leaders from among the most talented in the public service - for instance, an annual conference of second-division officers began in 1954, emphasising special skills for senior administrators. Initially, programs such as the Deputy Secretary Program (DSP) - identifying potential nextgeneration leaders - provided tailored individual plans including career placements or secondments, orchestrated workplace experience, senior shadowing, senior expertise in policy development as well as managing technical and functional areas of government. The DSP was essentially a nurturing program for identified senior executives with a largely domestic focus. Such programs were typically run by the relevant public service boards for cohorts of internal participants who had seniority and/or were deemed to have leadership potentialalthough there was some scepticism about whether such headstart/elite programs were actually successful and whether the next generation of leaders actually emerged from these identified cohorts. The federal DSP gradually gave way to more international/comparative leadership programs, such as the annual Leading Australia's Future in the AsiaPacific (LAFIA) study tour program, which was established in 2000 and provided senior executives with a greater understanding of Asia's economic growth and political regimes to encourage greater engagement with Asia and the Pacific. LAFIA was a contractual program undertaken as a joint initiative between the Australian Public Service Commission (APSC) and The Australian National University (Crawford School) and, by 2015, it had trained more than 300 senior executives. Elsewhere across the public service, senior executive development was also promoted by deputies' forums such as the APS200 group (a deliberative/shared learning exchange) plus various learning centres and talent management exercises. Other international-focused dialogue events/forums include the Harvard Club of Australia, the Australian American Leadership Dialogue, the Greater China Australia Dialogue, the Indonesia-Australia Dialogue, as well as domestic bodies such as the Lowy Institute and the Grattan Institute. 


\section{Recent evaluations of Australia's commitment to training and executive development}

In March 2010 a new blueprint for the reform of Australian government administration, entitled Ahead of the Game, was publicly released. While it noted that the existing performance of the APS could be assessed overall as comparable with some of the world's best public services, the case for further reform was strongly supported. One of its major findings was that the APS was underinvesting in its talent, particularly in comparison with the private sector, where estimates were that as much as 80 per cent of a company's worth could be tied up in its employees and their human capital. Across Australia's private sector, average expenditure on employee development floated at about 4 per cent of their total budgets. In comparison, almost half of APS agencies reported spending less than 1 per cent of their budget on staff development. Only a small proportion reported spending amounts comparable with the best private sector organisations. In addition, the quality of learning and development was identified as a problem, with fewer than one in three APS employees rating the effectiveness of their learning and development program as high or very high in terms of helping them improve performance.

The Ahead of the Game report identified significant challenges faced by government in respect of executive development, which were that:

- a generational shift was occurring in the leadership group

- there was a shallow pool of successor talent

- there were real difficulties in delivering a breadth of experience to future leaders

- governments had made low investment (compared with bestpractice corporations) in the development of executive talent

- there was difficulty in giving senior executives 'time out' to refresh and reflect

- there was a pressing need to attract high-potential graduates to public sector careers.

In response, reforms recommended in Ahead of the Game-and unanimously endorsed by the Australian Government-aimed to enhance agency agility, capability and effectiveness, and expand and 
strengthen learning and development. Consultations with stakeholders identified the need to improve leadership and management across the APS. Specific gaps in performance and capability were identified as people management skills, the capacity to steer and implement change and the capacity to think strategically. Specific recommendations included:

- strengthening the role of the APSC to drive the reform strategy

- establishing a leadership development centre that utilises bestpractice talent development from the public and private sectors.

Recommendations also required the APSC to develop a stronger relationship with specialist providers of leadership development programs across Australia to ensure 'capacity exists to meet increased demand for high quality professional development' (Australian Government 2010: 60). The report called for more political and executive 'buy-in' for dedicated training, more robust engagement with the contours of supply and demand in training markets and the development of more structured or segmented markets and accredited providers. It also noted that many traditional issues of concern were still relevant today - namely: the relevance of training, its applicability or operability to those undertaking training and whether agencies were making best use of innovation strategies and were open to new ideas and management practices.

\section{The Australia and New Zealand School of Government: A unique response to building executive capabilities}

A significant innovation in the Australian context is the formation of a dedicated executive development institution, the ANZSOG. In its promotional material, the school committed itself to become:

[A] world-class centre providing cutting-edge research and tailored learning opportunities for future leaders of the public sector. ANZSOG's purpose is to encourage improved public sector leadership, decision-making, policy outcomes and performance for the benefit of the community. ANZSOG plays a crucial role in promoting public service as a vocational profession of great social value to the public interest. (ANZSOG n.d.) 
To achieve these ambitious objectives, ANZSOG concentrated on three core functions:

1. To provide executive education development including the Executive Fellows Program for senior executives and the Executive Master of Public Administration degree for mid-career government officials.

2. To produce a high-quality teaching case study collection available for training and executive development (currently about 220 cases are available for use).

3. To undertake an active research program investigating topics of immediate relevance to public sector managers 'to deepen knowledge and understanding of government and to disseminate that understanding throughout the community' (ANZSOG n.d.). ${ }^{4}$

While these lofty intentions would seem logical and far-sighted, the creation of ANZSOG was actually brought about because other specialist or tertiary institutions were not providing these functions, or not providing them to the satisfaction of key public sector leaders. ANZSOG was the response to the perception of various Australian governments that there was a 'market failure' in the provision and quality of training and development programs available for public sector executives, especially focused on public leadership and management. Governments therefore took the initiative and made the necessary investments to create, with the collaboration and support of leading universities across the two nations, their own multijurisdictional school of government to which they could send their mid-senior executives identified as likely future leaders.

\section{Establishment of the school in 2002}

The establishment of ANZSOG about the turn of this century reflected a proactive recognition that the task of designing, delivering and maintaining the quality of professional development for future public

4 These objectives have changed only slightly since 2002-03. The most recent statement of the school's objectives claim its purpose is 'dedicated to creating value for citizens by providing world-class education for public sector leaders, conducting research and facilitating informed discussion on issues that matter for public sector performance, and promoting and supporting innovation in the public sector' (ANZSOG 2014). Only the last phrase is an augmentation of earlier statements. 
sector leaders is challenging governments and specialist educational providers across the world. Existing approaches range from reliance on dedicated government-owned institutions (such as the Singapore Civil Service College and the French National School of Administration) to specialist institutes attached to leading universities. In this latter category the United States, for example, has a number of world-class providers such as Harvard's John F. Kennedy School of Government, the Brookings Institution, the Woodrow Wilson School of Public and International Affairs (Princeton) and the Goldman School of Public Policy at the University of California, Berkeley. Recent UK experience has witnessed the demise of the government-owned National School of Government in 2012 (Civil Service College and Cabinet Office), although new initiatives have emerged as replacements, such as the Oxford University Blavatnik School of Government, as well as continuing roles for established providers such as the London School of Economics and Warwick University.

Against this background, Australian and New Zealand public sector leaders determined to pursue a distinctively different approach to executive development, one that attempted to harmonise and build on the respective capacities of governments and universities across the two nations. Their innovative vision and subsequent work resulted in the creation of ANZSOG, founded in 2002.

The history of the school and how it came to be established in the form in which it has operated continuously since its formation can be traced back to the mid-1990s, especially to public debates about how Australia could best build a world-class graduate school to train senior business executives in the private sector. The initial focus of these debates was on developing elite business schools to encourage entrepreneurial skills in the next generation of business leaders. An influential report to the Australian Government in 1995 by the Industry Task Force on Leadership and Management Skills, chaired by David Karpin and known as the Karpin Report, found:

One of the principal criticisms of Australian management schools $\ldots$ is that, while individual academics and departments within some schools are world class, it is unlikely that there is a world class management school in Australia. The principal issue is one of scale, in that none of Australia's leading schools approaches the size 
the Task Force considers necessary to provide the infrastructure most likely to support world class quality in teaching and research. A world class school is vital to provide leadership to the rest of the postgraduate management sector and to assist Australian enterprises by promoting the latest management thinking. (Karpin 1995: 41)

While the focus of the Karpin Report was explicitly on the development of private sector executive leadership, its conclusion was equally apposite to Australia's public sector, where, arguably, the problems were more pronounced. While many universities had graduate programs aimed at public officials, they were all constrained by limited demand, comparatively small and regionally focused academies and limited and highly conditional support from public service leaders. There was also a growing concern that the executive development of public executives was becoming a case of market failure: a dissipated and fragmented pattern of tertiary education institutions not investing sufficient resources to produce the required specialist courses and training opportunities that governments needed and requested. There was a view across the public sector that universities at the time were not providing the required intellectual perspectives or teaching expertise necessary to meet governments' needs. And, accordingly, a new consolidated model was needed to provide world-class public sector executive education.

The release of the Karpin Report stimulated renewed discussion among public sector leaders about whether a similar case should be made for the development of public sector management and leadership capability. While there was endorsement of the need, exploratory discussions with Federal Government department heads and some scoping research, the idea did not gain sufficient traction through the 1990s to establish a critical mass of government support.

Exploratory discussions resumed again in 2001 when then secretary of the Victorian Premier's Department, Terry Moran, established a working group to consider whether there was sufficient interest in and a credible business case for a world-class 'school of government'. Soundings were taken from public sector, private sector, university and business school leaders, with a consistent message that any proposed development would need to be underpinned by a wellresearched business plan and strong support from both government and universities. 
To investigate potential demand and develop a credible business case, the Boston Consulting Group (BCG) was engaged. BCG's November 2001 report concluded that across Australian governments there were market demand and strong support for a national school of government. BCG's (2001) advice, however, was that:

- implementation of the proposed school would require a comprehensive communication campaign to broaden the basis of support and translate 'in-principle support' to 'actual support', as well as firm commitments to student numbers

- across government, chief executive officers (CEOs) and senior line management should be targeted in a face-to-face communication campaign because key stakeholder support for the new school was essential.

BCG's work also concluded that there were sufficient expertise and sufficient teaching staff (academics and practitioners) to establish a world-class faculty but the expertise was dispersed across the nation. Their conclusion was that the new school would need to draw on faculty from around Australia and include practitioners among its teaching staff. The new school's faculty staff would need to be regarded by governments as outstanding and be accomplished teachers as well as renowned academics, and able to draw extensively on practical experience. Overall, BCG's conclusion was that there was market demand for the proposed offerings of a new school and a good basis of support on which to build.

The majority of preparatory work during the balance of 2001 and much of 2002 focused on securing the necessary support from governments and universities, including some early curriculum discussions involving practitioners and academics. One unexpected but particularly opportune development was the high level of interest expressed by the New Zealand Government and Victoria University of Wellington (VUW) in joining the new school. In many ways, this unplanned support crystallised the opportunity and benefits of collaborative action across government and universities.

By mid-2002, the five 'foundation members' had been identified with commitments to fund the agreed intake for both ANZSOG's Executive Master of Public Administration (EMPA) and Executive Fellows Program (EFP) for at least the first three years. Governments emphasised 
that support beyond this initial commitment was dependent on ANZSOG's performance. In November 2002, the founding government and university members signed an agreement. In early 2003, the appointment of the inaugural dean was announced (Professor Allan Fels), key staff were recruited and work was completed on detailing the EMPA curriculum, accredited as a new master's degree by the academic boards in each of the nine founding member universities. ${ }^{5}$

Enrolment of the initial 130 public sector managers in the inaugural EMPA was completed and delivery of the week-long course on 'Delivering Public Value' occurred in May 2003, with the balance of the 10-course master's program delivered through 2003 and 2004. The inaugural delivery of the EFP occurred across October and November 2003, with an enrolment of 80 senior public officials from across Australia and New Zealand, and a faculty drawn from Australian, New Zealand, US and UK universities, and Australian and New Zealand public sector leaders.

Since 2003 the EMPA and EFP have been delivered each year, with more than 2,295 public servants completing one of the two programs by 2015. ANZSOG programs also have expanded to include a program for public sector managers making the transition from operational to strategic leadership roles ('Towards Strategic Leadership'), an extensive range of executive education short courses, programs aimed at building public sector capability in the AsiaPacific, a leadership development program for local government and an increasingly active research program (see ANZSOG 2013, 2016). By 2015 there was a total of 3,393 alumni across all programs (but not including executive education short courses).

Important features distinguishing ANZSOG from other international public service training institutes, such as the former UK National School of Government, are the role of and investment in researchresearch that underpins the core curriculum and informs and supports teaching. In this domain, a key initiative of the Australian Government was its agreement to fund, with matching support from

5 The five original jurisdictional members were the governments of the Commonwealth of Australia, New Zealand, Victoria, Queensland and New South Wales. The nine founding university members were The Australian National University, University of Canberra, Victoria University of Wellington, Monash University, Melbourne Business School, Griffith University, University of Queensland, Sydney University and the University of New South Wales. 
The Australian National University, the Sir John Bunting Chair of Public Administration. Professor John Wanna was the inaugural appointment to the chair and led an extensive research and publications program, including supervision of doctoral students, some of whom may develop as future teachers of ANZSOG programs. This was followed by a series of other government-sponsored senior academic research posts in other member jurisdictions, as well as joint teachingresearch appointments. ANZSOG has also invested heavily in the development of executive-level teaching cases, overseen initially by Professor John Alford and Janet Tyson, with an available library now of more than 200 written case studies. In addition, under the guidance of a research committee chaired initially by the head of the Australian Treasury, Ken Henry, and then by the second Dean, Professor Gary Banks, ANZSOG provides modest project funds on a contestable basis for research that meets the priority needs of government and that supports and informs future teaching.

While ANZSOG naturally shares many characteristics with other schools of government, it also has several distinctive features. These can be summarised by the following:

- ANZSOG is a consortium of stakeholder governments and universities designed to achieve economies of scale and scope addressing the needs of government.

- It is a collaborative partnership between multiple jurisdictions across two closely related nations (Australia and New Zealand).

- Government identifies its emerging leaders from around Australia and New Zealand, and supports them financially during their engagement with ANZSOG.

- The school has the capacity to attract first-class teachers from Australia, New Zealand and overseas.

- Its rigorous EMPA is accredited by Australian and New Zealand universities.

- The school offers a research-driven, practitioner-oriented curriculum.

- Its pedagogic philosophy stresses innovative and engaging program delivery.

- It has strategic linkages with other prestigious international schools of government in Europe, America and Asia. 
With aspirations to be recognised as a significant school of government within the Asia-Pacific region, ANZSOG has also designed and delivered a range of programs for public officials working in other countries. Sponsored places in ANZSOG core programs were offered through scholarships provided by prime ministers Howard and Clark from 2003. Each year a small number of senior leaders from SouthEast Asian nations attend the three-week EFP, establishing lasting relationships with Australian and New Zealand public sector leaders. Between 2007 and 2013, with the support of the Australian Agency for International Development (AusAID) and the Department of Foreign Affairs and Trade (DFAT), ANZSOG delivered a senior leadership program to public officials from 10 Pacific nations (the Pacific Executive Program, or PACE). It has also delivered a series of capacity-building programs - again, with AusAID support - to emerging public sector leaders in Indonesia. ANZSOG's priority focus on senior leadership development was also reflected in delivery of the China Advanced Leadership Program and Indian Advanced Leadership Program from 2011. And it has provided input to DFAT's sponsored 'leadership precinct' in Papua New Guinea.

ANZSOG's journey to date has maintained, and broadened, strong high-level support from its 10 governments and 15 university owners. Over the 12 years to date, delivery of ANZSOG programs has seen the following:

- 1,383 Australian and New Zealand 'high potentials' complete or completing the EMPA. The average overall participant rating for the program is 4.0 (on a five-point scale). Follow-up surveys of alumni indicate more than 60 per cent of graduates have been promoted since completing the program.

- 912 Australian, New Zealand, Chinese Singaporean, Canadian and Indian public sector leaders have completed the EFP, with an average overall participant evaluation of 4.24.

- There are now more than 200 heads of department and agencies in Australia and New Zealand who have completed ANZSOG's CEO forum, led by Professor Mark Moore from the Harvard Kennedy School.

- 186 public sector leaders from Pacific Island nations have completed or are completing the PACE program, with an average participant rating of 4.8 . 
- More than 200 teaching case studies have been researched and written, drawn from Australian and New Zealand public sector agencies and now accessed worldwide by teachers, plus more than 50 research monographs produced through ANU Press, together with various occasional paper series available on the ANZSOG website.

- Alongside these core programs, between 30 and 50 specialised executive education workshops have been delivered each year for public officials working for ANZSOG's member governments.

- The past few years have seen an increased emphasis on 'policy roundtables' devoted to issues of concern to member governments and conducted under Chatham House rules.

When examining the factors that appear to have contributed to ANZSOG's progress and the continuing high level of support it enjoys from both its government and its university owners, six factors stand out. First, the school prioritises a continuing focus on meeting governments' needs in senior executive development, with the corollary that continuing support from government stakeholders requires maintaining relevance and high levels of customer satisfaction. Second, it has invested in a significant commitment to research that informs teaching and learning, often hosting pro bono forums and workshops for stakeholder governments. Third, it demonstrates a commitment to teacher development focused on effective postgraduate/mid-career teaching and learning. Fourth, it actively utilises an extensive network of scholars and practitioners, across Australia and New Zealand and internationally, to provide input into programs and courses. Fifth, the school maintains an active engagement with and support from alumni, including providing ongoing educational refreshers and network opportunities. And, finally, the school operates with a robust business model designed to maximise its effectiveness and influence, while providing value for money for governments and participants.

Cumulatively, these factors have generated and sustained ANZSOG's development to date and provide a robust foundation on which further development can be built. Future development will need to address the ongoing challenges of ANZSOG's comparatively small scale and related traditional reliance on a comparatively small number of academics able to teach successfully in its programs. As most of these have been guest presenters and adjunct staff, a continuing challenge 
is sustaining a strong sense of collective ownership of key programs. Periodic reviews by independent experts of teaching quality and pedagogies, as well as research agendas and published contributions, will continue to be important to the school's ongoing contribution.

\section{Conclusion}

Australia has relied on a fragmented matrix of training and educational providers, combining in-house on-the-job training for staff with more technical and intellectual education available across the public sector. At times, such training needs have been coordinated by central agencies, which also tended to provide some basic and specialist courses within their jurisdictions. Historically, training was often loaded towards the induction stages of employment with sporadic training offered towards mid-career grades. In the past five decades, training and development philosophies have been oriented towards developing managerial skills and encouraging the inculcation of leadership qualities. The marketplace for educational and training providers has proliferated and deepened, not only through the provision of tertiary courses (addressing different levels of demand) but also through the growth of private sector providers offering relatively specialised training and development. The experiment with ANZSOG is unique in that it provides an interjurisdictional locus for executive development, working closely with expert scholars and practitioners, but 'owned' by the stakeholder governments themselves.

\section{References}

Australia and New Zealand School of Government (ANZSOG) n.d. The Establishment of the School. Melbourne: ANZSOG.

Australia and New Zealand School of Government (ANZSOG) 2013. Annual Report 2012. Melbourne: ANZSOG.

Australia and New Zealand School of Government (ANZSOG) 2014. Annual Report 2013. Melbourne: ANZSOG.

Australia and New Zealand School of Government (ANZSOG) 2016. Annual Report 2015. Melbourne: ANZSOG. 
Australian Government 2010. Ahead of the Game. Canberra: Australian Government.

Australian Institute of Management (AIM) 2013. Learning and Development in the Public Sector. August. Sydney: AIM.

Australian Public Service Commission (APSC) 2004. Integrated Leadership Capability Framework. Canberra: APSC.

Betts, J. J. 1949. The training of Commonwealth public servants. Public Administration (AJPA) 8(2-3) (June-September).

Boston Consulting Group (BCG) 2001. Australian Graduate School of Government: Development of a business model. Final report, November. Melbourne: BCG.

Caiden, G. 1965. Career Service: Introduction to the history of personnel administration in the Commonwealth Public Service of Australia 1901-1961. Melbourne: Melbourne University Press.

Caiden, G. 1967. The Commonwealth Bureaucracy. Melbourne: Melbourne University Press.

Crisp, L. F. 1972. Politics and the Commonwealth Public Service. Australian Journal of Public Administration 31(4): 287-309.

Crisp, L. F. 1978. Australian National Government. 4th edn. Melbourne: Longman Cheshire.

Davis, G. and Rhodes, R. A. W. 2000. From hierarchy to contracts and back again: Reforming the Australian Public Service. In M. Keating, J. Wanna and P. Weller (eds), Institutions on the Edge? Sydney: Allen \& Unwin.

Davis, G. and Wanna, J. 1997. Does the teaching of public administration have a future?' Australian Journal of Public Administration 56(4): $1-5$.

Di Francesco, M. 2015. Policy analysis instruction in Australia. In B. Head and K. Crowley (eds), Policy Analysis in Australia. Bristol: Policy Press.

Fels, A. 2003. The Australian and New Zealand School of Government. Canberra Journal of Public Administration (108) (June). 
Hennessy, P. 1988. Whitehall. London: Secker \& Warburg.

Karpin, D. 1995. Industry Taskforce on Leadership and Management Skills. [Karpin Report]. Canberra: AGPS.

Parker, R. 1993. The Administrative Vocation. Sydney: Hale \& Iremonger.

Patapan, H., Wanna, J. and Weller, P. (eds) 2005. Westminster Legacies. Sydney: UNSW Press.

Podger, A. 2003. Trends in the Australian Public Service, 1953-2003. Canberra Bulletin of Public Administration (109) (September).

Public Service \& Merit Protection Commission (PSMPC) 2001. Serving the Nation: 100 years of public service. Canberra: PSMPC.

Public Service Commission (PSC) 1992. Accounting for Your Training Dollar. Canberra: PSC.

Spann, R. N. 1973. Government Administration in Australia. Sydney: George Allen \& Unwin.

\section{Appendix 2.1}

\section{Key milestones in executive development and staff training in the Australian Public Service}

1933

1937

1943
A new section (36A) was inserted into the Commonwealth Public Service Act 1933 to provide for the appointment of university graduates to the service, as base-grade clerks.

The Department of External Affairs began to recruit a small number of clerks (above base grade) with qualifications and knowledge, oriented particularly to the department's international activities.

Introduction of a more formal cadetship scheme in the Department of External Affairs; 12 cadets were selected and sent to the University of Sydney for full-time intensive training and study in selected subjects. 
Provision for the Public Service Board to grant extended unpaid leave (up to three years) to allow officers to undertake courses of study relevant to the duties of their respective offices and to meet postwar reconstruction needs. Establishment of Central Training Section to coordinate service-wide training.

Early 1950s Australian Administrative Staff College established (it later became the Mount Eliza Business School and then merged with the Melbourne Business School).

Abolition of the diplomatic cadetship scheme instituted in 1943. The original short, intensive period of training at the University of Sydney was superseded by a twoyear course at the then Canberra University College (linked to the University of Melbourne), where a special postgraduate School of Diplomatic Studies had been established.

1958 In Canberra, the Brassey House training centre was opened as a service residential training centre in December 1958, for use both by the Board and by departments. Its facilities were expanded in 1964-65.

1959 The Boyer Report into recruitment and training was released, stressing the employment of more graduates.

Early - Central training in new technologies and statistical mid-1960s packages, automatic data processing. 
1963 Board intensive training scheme for its own graduate recruits, which evolved into the wider-ranging Administrative Trainee Scheme (ATS), with consistent annual intakes of between 20 and 35 graduates from 1965 onwards. This was a one-year highly integrated training scheme with some 11 weeks of course work and, normally, three different, carefully selected work placements.

1966 New graduate recruitment procedures were introduced, with upgraded selection techniques and significantly improved induction and training arrangements.

Early 1970s Increased numbers of graduate entrants and agencies increased the number of staff undertaking part-time university studies (including some fee reimbursement and provision of study time in work hours).

1974-76 The Coombs Royal Commission was critical of public service training, saying much was not linked to the objectives of the organisation. The Royal Commission supported more emphasis on tertiary education supplemented with specialist courses and on-the-job training. It argued the Public Service Board should act as a 'resource bank' for improving the quality and delivery in departments and agencies.

Late 1970s Greater emphasis focused on executive development schemes, interchange programs and senior women in management programs.

1981 Suspension of the ATS due to costs and in recognition of the progressive improvement that had occurred in APS graduate recruitment generally, with better provision by departments of induction arrangements and development opportunities.

1984 Senior Executive Service established as a dedicated leadership group, beginning to address leadership and development needs of this group.

1985 Reintroduction of the ATS. 
1989 The ATS finally discontinued, with training and development of graduate recruits to become solely a departmental responsibility.

1989 Establishment of the Joint APS Training Council (JAPSTC) - a direct consequence of award restructuring under the Industrial Relations Commission's Structural Efficiency Principle. The government also allocated A $\$ 10$ million per annum for the Middle Management Development Program, which included:

- the subsidisation of middle-management development activities

- and, importantly, the development of the Public Sector Management Course (PSMC) for middle managers in both the Commonwealth and the state public sectors, created by government but delivered by external university providers.

1990s JAPSTC sponsored curriculum development and training courses, including to SES level. The Commonwealth Government introduced the Training Guarantee Scheme requiring employers (including public sector agencies) to allocate funding to training needs.

1991-92 Development of a PSMC curriculum was undertaken by the University of Wollongong (then revised extensively on two occasions by Griffith University academics), with course materials then trialled in the Australian Capital Territory and four states; external providers along with staff from Griffith and Flinders universities and Queensland University of Technology were involved in delivery and quality assurance.

1992 SES development programs launched by the Public Service Commission, using the Senior Executive Leadership Capability Framework (SELCF), emphasising the critical success factors for improved organisational performance. 
1993

1993

1993

1994-95

1999-2000 The PSMC program was successfully delivered in Fiji and also piloted to other Pacific countries.

2000

2002

2004

Strategic Planning for Training \& Development (MAB) report, which led to the National Training Reform Agenda embracing competency-based training and identification of skills needed in the workforce.

PSMC middle-management course started with more than 600 Commonwealth and state participants in the first year, undertaking 170 hours of course contact time and a 40-hour work-based project. The first graduates received their certificates in May 1993.

Endorsement of the ABS core competencies by the National Training Board.

JAPSTC developing a framework for implementing competency-based training for APS entry levels through to middle management, using both external educational institutions and in-service resources.

Establishment of the National Public Administration Training Advisory Board, with the conversion of APSendorsed standards to national standards passed to that body.

Public Services Training Package directed towards providing individuals with clear skill and career pathways, through attainment of recognised qualifications from nationally recognised training providers.

Five government jurisdictions (Australia, New Zealand, Victoria, New South Wales and Queensland) collaborate with nine universities to establish ANZSOG, which takes its first intake of 130 students in 2003.

The Integrated Leadership System(ILS) program adopted by the APS (from the previous SELCF); the ILS uses five clusters of executive leadership capabilities (achieve results, cultivate productive workplace relations, communicate with influence, exemplify personal drive and integrity, and drive strategic thinking). 
2006+ The ILS stimulates agencies to customise and adapt the frameworks to suit agency needs; meanwhile, the framework is gradually incorporated into departmental staff appraisal and performance management systems.

2010 The Ahead of the Game report finds the APS is underinvesting in training and executive development and recommends renewed efforts to expand learning and development and enhance its quality to achieve high-quality professional leadership. 
This text is taken from Sharpening the Sword of State: Building executive capacities in the public services of the Asia-Pacific, edited by Andrew Podger and John Wanna, published 2016 by ANU Press, The Australian National University, Canberra, Australia. 